\title{
Upaya Hukum Bagi Pegawai Yang Rekeningnya Disalahgunakan Oleh Perusahaan
}

\author{
Natasha Anggraini dan Hari Soeskandi \\ Fakultas Hukum Universitas 17 Agustus 1945 Surabaya \\ Email Korespondensi: natashanggraini03@gmail.com
}

\begin{abstract}
Abstrak
Pembuatan rekening pribadi bank untuk keperluan perusahaan atau oknum lainnya banyak terjadi di kawasan perusahaan.Tidak sedikit juga beberapa orang yang bekerja di suatu perusahaan tersebut tidak menolak untuk rekening pribadinya tersebut dipakai oleh perusahaannya dengan maksud tertentu.Apabila diketahui padahal transaksi keuangan perusahaan yang menggunakan rekening pribadi seseorang akan sangat merugikan bagi mereka yang nomor rekening beserta namanya dipakai oleh perusahaan seperti kerugian dalam pencatatan akuntansi yang dicatat sebagai hutang dan juga piutang. Apabila di dalam perusahaan posisi sebagai hutang maka pihak pribadi bisa dianggap oleh kantor pajak telah menerima bunga pinjaman sehingga akan ditelusuri kedalam SPT pribadi $\mathrm{PPh}$ atas nama perorangan tersebut apakah sudah masuk ke dalam penghasilannya atau tidak. Setidaknya terdapat Undang-Undang Nomor 8 Tahun 1999 mengenai perlindungan konsumen.Ketentuan pasal ini Menjelaskan jika pegawai berhak atas mengetahui rekening pribadinya digunakan untuk apa atau berhak menolak untuk rekening pribadi nya dikelola perusahaan.
\end{abstract}

Kata Kunci: Pajak, Pribadi, Rekening

\section{PENDAHULUAN}

Bank yaitu memiliki fungsi yang paling utama dalam bidang perbankan dan merupakan suatu lembaga keuangan terhadap pemerintah, serta badan usaha bagi swasta maupun negara dan juga masyarakat umum. ${ }^{10}$ Setiap masyarakat yang memiliki rekening di bank pasti diberi fasilitas kartu Anjungan Tunai Mandiri (ATM), penggunaan sebuah ATM tersebut juga tidak terlepas dari suatu perjanjian perlindungan konsumen yang di upayakan oleh pihak pemerintah terhadap bank dan ATM sendiri adalah sarana teknologi yang dapat melayani kebutuhan nasabah selama 1x24 jam dalam tujuh hari dalam seminggu termasuk juga hari libur tanpa nasabah harus ke bank untuk mengambil ataupun transaksi keuangan. ${ }^{11}$ Dalam era globalisasi ini, semakin maju nya perkembangan ekonomi di suatu negara maka banyak juga hal-hal kejahatan seperti korupsi, pencucian uang atau menyembunyikan dana perusahaan di rekening pegawainya agar terhindar dari pajak kerap terjadi. Dalam kegiatan transfer dana antar bank dalam rekening perusahaan ke rekening pegawai itu dalam ketentuan pidana di UndangUndang No. 3 Tahun 2011 Tentang Ketenagakerjaan (selanjutnya disebut UU Ketenagakerjaan) perihal pemindahan dana yang menjelaskan perlindungan hukum serta pengamanan rekening pribadi pegawai itu sangat perlu guna menjaga integritas sistem perbankan keseimbangan perlindungan yakni pada pihak bank dan nasabah, serta menghindari adanya tindak pidana.

Tindakan transfer dana antar bank dari rekening pribadi pegawai kepada rekening perusahaan ini sudah menyimpang dari hak-hak yang dimiliki pegawai karena secara tidak

\footnotetext{
${ }^{10}$ Zaenal Asikin, Pokok-Pokok Hukum Perbankan Di Indonesia, II. (Jakarta: Raja Grafindo Persada, 1997). h.4

${ }^{11}$ Kasmir, Dasar-Dasar Perbankan (Jakarta: PT. Raja Grafindo Persada, 2008), h.182
} 
langsung pihak perusahaan akan mengetahui pin ATM dan juga data pribadi milik pegawai yang dirahasiakan oleh bank. Posisi pegawai ialah tidak terikat pun juga setara. Tetapi faktanya, kedudukan pemberi lapangan kinerja dengan pegawai sering terjadi hal pada kondisi yang tidak sesuai. Adapun halangan masalah masih ditemui yang di antaranya ialah sebab kultural baik bagi pegawai, pemberi lapangan kerja, juga penegak keadilan. Meskipun dari teori pemberi lapangan maupun penerima kerja ialah memiliki kedudukan yang seimbang namun dalam praktek dan fakta di lapangannya sangat berbeda dalam hal keterampilan dari bagian perussahaan pada pemberian hak-hak pegawai atau pegawainya. Perihal ini berkaitan dengan hukum ketenagakerjaan yang memiliki pengertian hukum yang berkaitan dengan tugas yang dilaksanakan pemberian atasan bagian lainnya juga melalui pemberian yang sesuai langsung sesuai dengan tugas itu. ${ }^{12}$

Perseroan Terbatas adalah makhluk hukum atau badan hukum yang memiliki individual ,perseroan ialah bentuk yang berbeda juga berlainan dari pemiliknya, pada perihal ini melalui pemilik saham PT tersebut. ${ }^{13}$ Pada hakekatnya pimpinan atau pemegang saham tersebut bisa melaksanakan pemindahan dana melalui ATM maupun alat transaksi finansial lainnya dari dana perusahaan lalu ke rekening pegawainya ,namun akibat hal ini masih sering dijumpai kasus tindak pidana pencucian uang atau pengalihan penghindaran pajak dengan cara memakai rekening pegawai untuk perpindahan dana tersebut dan menyalahgunakannya yang berakhir pegawai pun akan terkena hukuman pidananya juga apabila mengandung unsur tindak pidana didalamnya. ${ }^{14}$ Pegawai harus memiliki sebuah perlindungan yang berkeinginan guna memberi keberlangsung model relasi kerja dengan kesesuaian tanpa terdapat beban dari pihak yang kuasa kepada yang tertindas. ${ }^{15}$ Proses diterimanya karyawan ke suatu perusahaan harus dengan perjanjian kontrak awal yang memang harus dipahami dan juga disetujui oleh tenaga kerja, apabila tidak adanya perjanjian dari awal hal tersebut akan membebani pegawai itu sendiri. Beberapa kasus yang sudah terjadi, kerap sekali pihak perusahaan menyembunyikan dana perusahaan ke rekening pegawai-pegawai nya agar terhindar dari pajak dan juga menyalahgunakan rekening pegawai tersebut seperti adanya pembelahan transfer lewat setoran dengan cash dalam akumulasi kecil ke sebagian rekening pekerja nya hingga akumulasi total transaksi setoran itu jadi amat tinggi. Hal tersebut harus dihindari karena apabila ada resiko terbesar perusahaan menyalahgunakan dengan tindak pidana korupsi pun, pegawai yang rekeningnya dipakai tersebut bisa saja kena hukuman pidana nya karna dianggap membantu proses pencucian uang atau bahkan korupsi oleh perusahaan. Terkadang pihak bank juga akan menimbulkan pertanyaan apabila pegawai melakukan transaksi dalam jumlah besar terutama saat transaksi pemindahan dana dari rekening pribadi pegawai ke rekening perusahaan yang semula rekening pegawai tersebut tidak aktif bahkan tidak relevan maupun tidak cocok dengan upaya nasabah itu. Di era globalisasi dan semakin canggihnya teknologi saat ini, makin banyak tindak kejahatan yang dengan mudah dilakukan dan dikelabuhi dengan hal-hal seperti itu, ditambah adanya fitur e-banking yang akan memudahkan siapapun bisa meng akses rekening pribadi seseorang apabila seseorang tersebut mengizinkan rekening pribadinya digunakan oleh pihak lain. Seperti contoh suatu perusahaan memerintahkan pegawainya untuk membuat rekening atas nama pribadi pegawai tersebut namun yang mengelola rekening tersebut adalah perusahaan, dan perusahaan bisa menjalankan atau meng akses e-banking pegawai tersebut

\footnotetext{
${ }^{12}$ Sedjun H. Manulang, Pokok-Pokok Ketenagakerjaan (Jakarta: Rineka Cipta, 1987). h.2

${ }^{13}$ M. Yahya Harahap, Hukum Perseroan Terbatas (Sinar Grafika, 2009). h.57

${ }^{14}$ Ibid.. h.71

${ }_{15}$ Abdul Khakim, Dasar-Dasar Hukum Ketenagakerjaan Indonesia (Bandung: PT. Citra Aditya Bakti, 2014). h.99
} 
dengan sangat mudah. Meskipun demikian, peristiwa-peristiwa yang sering terjadi bagi pengguna e-banking makin lama makin luas dan semakin bermacam jenis modus nya atau jenis motif transaksi seperti yang digunakan oleh perusahaan.

Minimnya pembagian informasi dan juga wawasan yang disajikan bagi pihak bank juga dapat menimbulkan makin besarnya tingkat margin rugi nasabah saat emnggunakan e-banking. Bank mestinya transparan saat mengadakan Good Corporate Governance juga meninformasikan ke nasabah atau public dengan konsisten dan juga secara teratur agar nasabah dan pihak manapun bisa menjaga kerahasiaan pin maupun data e-banking nya dan juga rekening pribadinya. ${ }^{16}$ Selain itu bank sendiri juga mesti melakukan pengajaran juga ke nasabah emngenai aktivitas operasional juga produk maupun jasa bank guna meminimalisir munculnya informasi yang akan memberikan dampak negatif nasabah itu sendiri. ${ }^{17}$ Dalam mewujudkan kesejahteraan buruh atau pekerja sebuah perusahaan harus dibuatkan peraturan tertulis, yang mana peraturan tersebut berisi tenatng apa yang bisa dilaksanakan juga tidak bisa dilaksanakan bagi sebuah perusahaan, sebab perusahaan merupakan sebuah badan usaha yang memang dibuat untuk mencari keuntungan atau laba yang setiap perusahaan nya pun harus memiliki dasar dan juga kekuatan hukum. Tentunya permasalahan ini memiliki dasar tujuan dari keadilan sosial didalam bidang ketenagakerjaan antara pegawai dan perusahaannya yang bisa diberikan oleh satu diantara metode yaitu melalui cara melindungi pegawai atau para pegawai dari kekuasan yang tidak terbatas dari pihak majikan maupun pimpinan perusahaan dimana tempat mereka bekerja lewat sarana hukum yang berlaku. Pengayoman kepada tenaga kerja/pegawai ini bisa ditinjau di alinea ke empat di pembukaan Undang-Undang Dasar 1945 (UUD 45) dan Pasal 27 ayat 2, Pasal 28 D ayat 1 dan juga ayat 2. Perlindungan kepada para pegawai ini bisa dilaksanakan efektif dengan cara menyajikan pembinaan, sumbagan juga dengan cara menambah penghargaan dari hak-hak asasi manusia serta pengayoman fisik juga sosial ekonomi lewat norma dan aturan yang sudah ditetapkan. Pada Undang-Undang Nomor 13 Tahun 2003 perihal Ketenagakerjaan sendiri hanya menyebutkan mengenai hak dari pegawai terhadap perusahaan adalah perusahaan memiliki hak atas upaya dari kinerja pegawai, perusahaan memiliki hak guna menugaskan/mengatur pegawai maupun pegawai kerja nya dengan tuntutan memperoleh capaian yang telah ditentukan, juga perusahaan memiliki hak untuk melaksanakan putus kontrak hubungan kerja kepada pegawai apabila mengingkari tentuan yang sudah disepahami sebelumnya. Dalam hal ini apabila didalam perjanjian kontrak kerja awal tidak ada kesepakatan tertulis maupun tidak tertulis bahwa rekening pegawai dapat dipergunakan bebas oleh perusahaan seharusnya tidak boleh melakukan pemutusan hubungan kerja terhadap pekerjanya apabila pekerjanya menolak untuk rekeningnya dipergunakan oleh perusahaan, tetapi faktanya di lapangan sangat berbeda karena pegawai pasti akan memberikan rekeningnya karena belum adanya edukasi tentang hukum ketenagakerjaan sehingga mereka merasa takut akan terkena dampak pemutusan hubungan kerja oleh perusahaan dimana mereka bekerja. Dalam hal ini banyak sekali faktor-faktor pidana yang dapat dimanfaatkan oleh perusahaan apabila karyawan mau atau tidak segan-segan untuk memberikan pin ATM atau data pribadi rekeningnya terhadap perusahaan untuk proses transaksi antar perusahaan.Maka dari itu karyawan harus lebih berhati-hati lagi dan mempertegas untuk menolak apabila rekeningnya memang sengaja akan dipakai oleh perusahaan, terlebih lagi apabila memang tidak ada kontrak tertulis sebelumnya mengenai pemakaian rekening karyawan tersebut.Karna di era

\footnotetext{
${ }^{16}$ Frianto Pandia, Manajemen Dana Dan Kesehatan Bank (Jakarta: Rineka Cipta, 2012). h.228

${ }^{17}$ Ibid.
} 
globalisasi ini semakin beragam tindak kejahatan yang bisa dilakukan dan bisa menimpa orang lain yang tidak bersalah. Yang paling banyak terjadi adalah apabila Perusahaan seperti Perseroan Terbatas (PT) yang hendak menyembunyikan asset dan juga menghindari pajak. Strategi ini seringkali digunakan beberapa perusahaan untuk menghindari laporan pajak dengan memecah saldo perusahaan ke beberapa rekening karyawan bahkan rekening pribadi pemegang saham.Hal lainnya yang bisa terjadi adalah dengan menyembunyikan asset pribadi dari hasil korupsi yang tentunya tidak diketahui oleh karyawan. Salah satu efek negative bagi perusahaan adalah korupsi bisa menjadi hal biasa sehingga menjadi terbiasa bagi perusahaan memiliki sifat tidak jujur dan tidak bertanggungjawab. Dalam Pasal 8 Undang-Undang 20/2001 telah dijelaskan bahwa "Dipidana dengan pidana penjara paling singkat 3(tiga) tahun dan paling lama 15(lima belas) tahun dan pidana denda paling sedikit Rp 150.000.000,00 (seratus lima puluh juta rupiah) dan paling banyak Rp 750.000.000,00 (tujuh ratus lima puluh juta rupiah), pegawai negeri atau orang selain pegawai negeri yang ditugaskan menjalankan suatu jabatan umum secara terus menerus atau untuk sementara waktu, dengan sengaja menggelapkan uang atau surat berharga yang disimpan karena jabatannya, atau membiarkan uang atau surat berharga tersebut diambil atau digelapkan oleh orang lain,atau membantu dalam melakukan perbuatan tersebut". Dalam arti karyawan bisa terkena pasal tersebut karna bisa dituduh melakukan perbuatan perbantuan korupsi kepada perusahaan.

\section{METODE PENELITIAN}

Penelitian ini adalah penelitian hukum. ${ }^{18}$ Pendekatan yang digunakan dalam penelitian ini adalah pendekatan konseptual dan pendekatan Undang-Undang.

\section{HASIL PENELITIAN DAN PEMBAHASAN}

\section{Perlindungan Hukum Data Pribadi Karyawan}

Perlindungan terhadap karyawan atau para tenaga kerja serta hak-hak nasabah terutama karyawan di suatu perusahaan yang rekeningnya tengah dipakai perusahaan untuk transaksi pemindahan dana perusahaan, banyak sekali aspek yang didapat.Bagi pekerja yang tidak melaksanakan kewajiban atau juga tugasnya kedalam bekerja maka dia tidak akan mendapatkan upah.Didalam Undang-Undang tersebut tidak dijelaskan apabila rekening pegawai atau karyawan dapat dipergunakan oleh perusahaan yang berbentuk Perseroan Terbatas. Mengenai Perseroan Terbatas tersebut merupakan badan hukum yang jelas mempunya beberapa ciri personalitas nya sendiri yaitu ${ }^{19}$ :

1) Perseroan terbatas adalah wujud yang "terpisah" dan juga "berbeda" dari pemiliknya yang dimaksud adalah dari pemegang, saham, itu sendiri

2) Secara umum, eksistensinya tidak terancam oleh kematian, kebangkrutan maupun pengunduran personal investor saham dari suatu PT.

Perseroan Terbatas (PT) menjadi lembaga hukum ini adalah makhluk hukum yang mempunyai kekuasaan, berwenang untuk berbuat dan juga berperilaku sama dengan kewenangan yang, memiliki otoritas yang dikontrol dengan tegas layaknya mempunyai aset atas nama perusahaan. Jadi pada hakekatnya direksi yang maupun juga investor saham yang tidak bisa melaksanakan pemindahan uang korporasi ke rekening pribadinya ataupun rekening

\footnotetext{
${ }^{18}$ Peter Mahmud Marzuki, Penelitian Hukum, Kencana Prenada Media Group, Jakarta, h. 35.

${ }^{19}$ Harahap,.Op.Cit.h. 57
} 
karyawannya jika tidak ada dasar yang proaktif atas pembagian uang itu (kesepakatan kontrak awal korporasi dengan pimpinan maupun karyawan yang rekeningnya akan dipakai untuk pemindahan dana perusahaan). Perilaku pemindahan aset korporasi ke rekening individu investor saham tanpa landasan yang jelas bisa juga dinyatakan menjadi perilaku dalam mengoptimalkan rekening karyawan dan juga perusaahaan dengan suatu kepentingan pribadi ${ }^{20}$ Pada Pasal 4 Undang-Undang Perlindungan Konsumen No. 8 Tahun 1999 telah dijelaskan bahwa terdapat asas keamanan dan keselamatan konsumen yang ditujukan adalah agar baik perusahaan maupun konsumen (karyawan) memberikan jaminan perihal keamanan maupun keberlangsungan bagi pembeli ketika pemakaian sebuah barang/jasa. Yang artinya di awal kontrak kerja tidak ada perjanjian keamanan dalam hal pemakaian rekening pribadi karyawan, karyawan memiliki hak untuk menolak apabila rekeningnya akan dipakai oleh perusahaan tersebut.

Pada peningkatannya dalam menambah kinerja juga mengakumulasi kualitas karyawan, sant diperlukan jaminan hidup yang layak dan juga pasti individu yang bisa juga akan menyebabkan penambahan kualitas pegawai kerja yang sudah ada dengan menambah pengamanan hukum kepada para tenaga kerja yang mestinya relevan dengan harkat juga martabatdan juga hak asasi manusia itu sendiri. ${ }^{21} \mathrm{Hal}$ ini bersangkutan juga dengan hak asasi manusia yang dimiliki para pegawai untuk menjaga data pribadi dan juga keselamatannya dalam bekerja agar tidak dirugikan atau tidak dimanfaatkan oleh oknum-oknum yang tidak bertanggungjawa. Terdapat peningkatan era dan juga teknologi yang amat cepat sejauh ini, maka perlindungan kepada tenaga kerja menjadi hal yang amat penting dan mesti ditinjau dengan terdapat penambahan resiko dan juga tanggung jawab yang ditemui oleh para tenaga kerja atau para pekerja di suatu perusahaan. Secara tidak langsung pemberian atas lindungan hukum itu menjadi sebuah apresiai guna mengahrgai hasil kinerja dari para pekerja yang sudah membantu korporasi melalui cara memberikan ide-ide juga gagasan-gagasan yang sudah dirancangnya. Selain itu perlindungan hukum atau perlindungan ketenagakerjaan sesuai pancasila dan UUD 1945, bisa juga dinyatakan menjadi pembangunan ketenagakerjaan yang jadi bagian dari peningkatan maupun juga peningkatan nasional. Oleh sebab itu amatlah vital pemerintah guna menambah perlindungan hukum kepada tenaga kerja-tenaga kerja ini. ${ }^{22}$

Ketenagakerjaan sendiri di Indonesia juga telah dikaji di Undang-Undang Nomor 13 Tahun 2003 perihal ketenagakerjaan. Problematika-problematika yang ada didalam ketenagakerjaan yang muncul biasanya disebabkan belum terkoneksinya korelasi yang selaras diantara pengusaha maupun direksi perusahaan dengan pegawainya. Hal itu yang akan menyebabkan munculnya pemaknaan yang akan mengatakan jika permasalahan di ketenagakerjaan ini terdapat unsur ekonomis, unsur sosial politik dan juga unsur kesejahteraan sosial. ${ }^{23}$ Dan disini hubungan yang tidak harmonis juga pasti akan dirasakan juga oleh para pekerja yang dengan terpaksa memberikan rekening pribadinya, karena disini posisi tenaga kerja merasa tidak mendapatkan hak yang setara sebagai seorang tenaga kerja dan merasa tertekan tetapi tidak bisa berbuat apa-apa dan mereka takut apabila menolak kemauan dari pimpinan perusahaannya seperti memakai rekening pribadinya maupun memerintahkan para tenaga kerjanya membuka rekening baru atas nama pribadi namun yang mengkelola rekening tersebut adalah perusahaan guna menghindari pajak atau unsur yang tidak sesuai dengan

\footnotetext{
${ }^{20}$ Ibid. h. 78

${ }^{21}$ Abdul Khakim, Pengantar Hukum Ketenagakerjaan Indonesia (Bandung: PT. Citra Aditya Bakti, 2003). h.9

${ }^{22}$ I Made Udiana, Industrialisasi Dan Tanggungjawab Pengusaha Terhadap Tenaga Kerja Terlibat Hukum (Denpasar: Udayana

${ }^{23}$ Andrian Sutendi, Hukum Perburuhan, Cetakan II. (Bandung: Sinar Grafika, 2001). h.83
} University Press, 2018). h.26 
perjanjian kontrak pada saat awal kerja. Permasalahan ketenagakerjaan yang memang mesti memperoleh perhatian terkhusus yakni tentang pemberhentian kontrak kerja yang biasanya diartikan juga dengans sebutan PHK. Perusahaan sendiri akan bisa melaksanakan perilaku PHK kepada pekerjanya menjadi akibat dari digitalisasi ini dengan faktor jika korporasi yang berkaitan sedang melaksanakan tindakan efisiensi. Efisiensi yang diartikan pada hal ini ialah korporasi melaksanakan batasan pada penggunaan sumber daya kedalam tahapan yang sudah dipakai di korporasi yang berkaitan. Hal tersebut bisa ditinjau dari batasan pemakaian pegawai juga mencopotnya digantikan mesin maupun pergantian dari seluruh wujud yang bersifat manusia kepada wujud mesin/digital. Untuk karyawan sendiri PHK ialah sumber dari tidak adanya sumber mata pemasukan yang dapat menyebabkan hilangnya kualitas hidup juga bahkan kemakmuran dirinya juga keluarga sebab di realitaya sendiri jika mencari kerja bukanlah suau hal yang gampang karena banyak sekali saingan dan juga perusahaanperusahaan yang memang belum membutuhkan tenaga kerja manusia. Sebenarnya beberapa perusahaan tidak boleh mengancam atau bahkan PHK tenaga kerja nya dengan alasan pekerja tersebut tidak ingin untuk data pribadi ataupun rekening berserta keuangannya di kelola oleh perusahaan karena hal-hal tersebut akan memberikan dampak yang sangat berpengaruh bagi pekerja apabila terjadi hal-hal yang tidak diinginkan.Faktanya sendiri seorang pengusaha bisa melaksanakan PHK mesti sesuai landasan-landasan yang bisa dikaji Undang-Undang dan tidak dilaksanakan dengan egois tetapi dilaksanakan putusan kontrakn kerja tersebut mesti dimusyawarhkankan terlebih dahuku dari kedua belah sisi yang berkaitan padanya yakni diantara pengusaha dan maupun karyawan atau pekerja nya.Landasan-landasan PHK yang memang diperbolehkan oleh Undang-Undang ialah:

1. Jika pekerja melaksanakan pemberian pengunduran diri yang dilandasi oleh keinginannya sendiri dengan wujud tertulis dan mestinya tanpa terdapat dampak maupun tekanan dari pihak lain baik dari pengusaha juga rekan kerjanya.

2. Apabila pekerja telah mencapai usia pension yang seharusnya sesuai dengan apa yang ditentukan sebelumnya dalam perjanjian kerja ataupun sesuai dengan apa yang diatur didalam Undang-Undang

3. Saat pekerja tersebut telah meninggal dunia

Perusahaan harus bertindak adil dan tidak boleh menyalahi aturan serta hak yang dimiliki oleh tenaga kerja, karena sering terjadi ketika saldo rekening perusahaan mulai banyak, pimpinan perusahaan akan megalihkan dana perusahaan tersebut ke rekening pegawainya agar terhindar dari pajak, dan parahnya apabila memang transaksi tersebut tidak wajar dan mengandung unsur tindak pidana maka pegawai tersebut juga pasti akan terkena dampaknya karena rekening yang digunakan adalah atas nama pekerjanya bukan atas nama perusahaan.Pengertian bank sendiri adalah institusi atau perusahaan dari jasa keuangan yang mendapatkan keuntungan berdasarkan prinsip sebuah kepercayaan yang diberikan dari masyarakat yang memang ingin menabung atau menginvestasikan uang pribadinya ke jasa keuangan tersebut. Regulasi tentang bank dalam rangka menjalankan tugasnya.Bank Indonesia menyatakan bahwa,dalam mengesahkan anjuran dalam perbankan yang berisi sikap pribadi.Lalu pasal 26 UndangUndang Bank Indonesia berwenang untuk ${ }^{24}$ :

a. menghapus izin usaha bank

b. Memberikan izin pembentukan, pemindahan serta penutupan kantor cabang bank

c. Memberikan putusan wewenang serta kepengurusan bank

${ }^{24}$ Sentosa Sembiring, Hukum Perbankan, Edisi Revi. (Bandung: Mandar Maju, 2012). h.275 
Sesuai pasal 1 nomor 28 Undang-Undang Nomor 10 Tahun 1998 perihal perbankan mengatakan jika Rahasia bank yaitu seluruh perihal-perihal yang akan berkorelasi langsung dengan uang dan lain-lain dari nasabah bank yang tidak boleh secara terbuka atau terangterangan yang diungkapkan kepada pihak masyarakat atau kepada orang lain. Dalam hal ini yang harusnya wajib menjadi rahasia akan bank yakni, semua data serta informasi perihal seluruh aspek yang akan bersinggungan langsung dengan finansial serta data pribadi serta hal lainnya dari seseorang serta badan yang diketahui sebab aktivitas usahanya. ${ }^{25}$ Pendapat Munir Fuady yang memiliki penjelasan menurutnya rahasia bank ialah korelasi antara bank dengan bagian nasabah yang nyatanya tidak seperti relasi kesepakatan yang biasa. Namun tapi bagian relasi itu pun dapat menjadi juga suatu kewajiban guna sebuah bank supaya tidak membuka rahasia bagian nasabahnya kepada pihak lain terkecuali apabila diputuskan oleh perundangundangan yang sudah ada juga perihal ini yang disebut rahasia bank.

Kedudukan pegawai sebagai nasabah dan juga tenaga kerja dari suatu perusahaan sejauh ini masih dinilai sepele juga saat kondisi yang minim profit jika ada masalah-masalah hukum di internal bank maupun eksternal seperti permasalahan penyalahgunaan rekening terhadap pegawainya ${ }^{26}$ Hak privasi atau hak pribadi dari seorang nasabah yang bekerja menjadi pegawai di sebuah Perseroan Terbatas tentunya melekat pada diri setiap orang karena hal tersebut merupakan martabat setiap orang atau bahkan pegawai atau tenaga kerja yang memang harus dilindungi.Pihak bank pun harus benar-benar menjaga rahasia pribadi nasabahnya, meskipun ada seorang pemimpin perusahaan meminta data pegawainya secara cuma-cuma tanpa memberikan surat kuasa atau bahkan surat izin pun sangat tidak diperbolehkan karena hal tersebut adalah hal yang sangat mudah memicu terjadinya suatu tindak pidana. Penyalahgunaan data pribadi adalah satu diantara contoh tindakan pidana yang acap terjadi dan dialami ketika berkaitan dengan rahasia privasi nasabah, karena hal tersebut merupakan hal-hal yang memenuhi unsure-unsur perbuatan pidana seperti unsur tidak pidana pencurian dan unsure tindak pidana penipuan dan unsur tindak pidana lainnya.Dengan seiringnya perkembangan zaman pun banyak diciptakan segala apapun itu tentang teknologi atau internet, seperti mobile banking dan internet banking yang lebih menyesuaikan nasabah guna melaksanakan transaksi financial tidak pergi ke cabang bank tempat nasabah menyimpan dana nya. Akan tetapi hal itu pastinya akan lebih mudah untuk menimbulkan indikasi tindak kejahatan di dunia perbankan, karena dengan internet dan teknologi yang semakin canggih, data nasabah pun bisa diketahui oleh siapa saja yang bisa meng akses dengan cara-cara yang tidak sesuai ketentuan. Hal ini pun tentunya bisa dirasakan oleh para pegawai yang rekeningnya disalahgunakan oleh perusahaan, karena dengan mobile banking akan lebih memudahkan mereka melakukan perpindahan dana antar perusahaan satu ke perusahaan lainnya menggunakan rekening pribadi pegawainya dengan cara mengetahui password atau pin mobile banking dan internet banking pegawainya. Tentunya apabila nasabah atau seorang pegawai dari suatu perusahaan mengetahui atau paham lindungan hukum juga hak-hak hukum yang dipunyai, mereka bisa pula melaksanakan usaha hukum menjadi bagian dari lindungan hukum yang ada di dirinya. Perjanjian kontrak kerja dapat diartikan sebagai salah satu tindakan saat satu individu atau lebih terikat individunya ke satu orang lainnya atau lebih. Hal ini sudah dijelaskan juga kedalam Kitab Undang-Undang Hukum Perdata Pasal 1313.

${ }^{25}$ Muhammad Djumhana, Rahasia Bank (Ketentuan Dan Penerapannya) Di Indonesia (Bandung: PT. Citra Aditya Bakti, 1996). 
Sering terjadi beberapa pelanggaran Hak Asasi Manusia yang dialami oleh karyawan atau para tenaga kerja di suatu perusahaan.Salah satu faktor ini juga bisa terjadi karena minimnya pengetahuan masyarakat mengenai pentingnya perjanjian kerja atau perjanjian kontrak sebelum mereka melakukan tanda tangan persetujuan kontrak kerja.Pada tiap perjanjian yang sudah dibentuk, terlebih dahulu mesti terdapat syarat-syarat juga aturan yang wajib dilaksanakan oleh kedua belah pihak supaya kontrak yang akan maupun sudah dibentuk secara sah dan juga bisa dilegitimasikan. ${ }^{27}$ Menjadi syarat dari kontrak pada khalayaknya, hingga kontrak kerja mesti mencukupi persyaratan sahnya sebuah kontrak sesuai dari yang dimuat pada Pasal 1320 KUHPerdata.Ketentuan ini pun ada di dalam Pasal 51 ayat (1) dan (2) Undang-Undang Nomor 13 Tahun 2003, kontrak kerja dibentuk dengan tertulis maupun melalui verbal. Kontrak kerja itu sendiri merupakan sebuah hal yang absolut maupun sebuah hal yang nyata menghubungkan para pihak yang membentuk sebuah ikatan kontrak kerja tersebut. Didalam terwujudnya sebuah ikatan kontrak kerja maupun yang jadi asas-asas pada sebuah kontrak, yakni:

\section{Asas Kebebasan Berkontrak}

Dalam asas ini telah disebutkan dalam Pasal 1338 ayat (1) Kitab Undang-Undang Hukum Perdata yang mengatakan jika "Seluruh kontrak yang dibentuk dengan legal berlaku menjadi Undang-Undang untuk mereka yang membentuknya".Pasal itu sudah menyiratkan makna jika asas kebebasan perjanjian ini memberika kebebasan untuk kedua belah pihak guna membentuk maupun bahkan tidak membentuk ikatan,menentukan bentuk dan bagaimana perjanjiannya,menentukan juga pelaksanaan dan persyaratan dari suatu perjanjian tersebut.

\section{Asas Konsensualisme}

Dalam asas ini telah disebutkan pada pasal 1320 ayat (1) Kitab Undang-Undang Hukum Perdata yang mengatakan jika satu diantara syarat sah nya sebuah kontrak ialah kata sepakat maupun yang sudah dilegalkan dari kedua belah pihak. Asas ini mengatakan jika kontrak pada umumnya tidak dijadikan dengan formalitas, tetapi cukup dengan terdapat persetujuan diantara kedua belah pihak saja.

\section{Asas Kepastian Hukum}

Masih kepada Pasal 1338 ayat (1) Kitab Undang-Undang Hukum Perdata mengontrol perihal kepastian hukum. Asas ini ialah asas yang berkorelasi dengan dampak ikatan dari aspek hukum juga sebagaimana pasnya suatu Undang-Undang, pihak ketiga tidak bisa melaksanakan intervensi kepada substansi kontrak yang sudah dibentuk oleh kedua belah pihak.

\section{Asas Itikad Baik}

Asas ini menjelaskan jika para pihak, yakni pihak pertama dan juga pihak kedua mesti melakukan substansi kontrak kerja sesuai kepercayaan maupun keyakinan yang kuat juga keinginan baik dari para pihak.

\section{Asas Kepribadian}

Dalam Pasal 1315 Kitab Undang-Undang Hukum Perdata yang menjelaskan jika "seseorang tidak bisa melakukan suatu kontrak kecuali bagi dirinya pribadi". Pasal itu juga mengandung sesuatu guna melakukan sebuah kontrak harus bagi kegunaan dirinya pribadi.

\section{Asas Kesetaraan}

Asas ini menempatkan kepada kedua belah pihak bahwa para pihak ini memiliki derajat atau kesetaraan yang sama, walaupun mempunyai perbedaan fisik, bangsa, kekayaan maupun otoritas. Asas ini ditujukan supaya kontrak bisa menjadikan profit yang adil untuk para pihak.

${ }^{27}$ Richard Burton Simatupang, Aspek Hukum Dalam Bisnis (Jakarta: Rineka Cipta, 2007). h.28 
Pentingnya perjanjian kontrak kerja di awal kerja itu sangatlah penting, dan harus adanya persetujuan antara kedua belah pihak antara calon pegawai dan pihak perusahaan.Karena sering terjadi adanya hal-hal diluar ketentuan dalam bekerja seperti hal nya rekening pegawai yang dipakai oleh perusahaan untuk pemindahan dana suatu perusahaan ke perusahaan lainnya dan hal itu disalahgunakan untuk hal negatif seperti sengaja memecah dana ke beberapa rekening pegawainya untuk menghindari pajak dan hal lainnya yang akan merugikan pegawai itu sendiri walaupun pegawai tidak ada maksud melakukan aksi tindak pidana atau kecurangankecurangan lainnya yang menyangkut pihak pribadi pegawai tersebut dan juga perusahaan dimana dia bekerja. Perlindungan hukum bagi pegawai atau pekerja di suatu perusahaan memang sudah beberapa tercantum didalam undang-undang,namun memang secara teori dan faktanya saat di lapangan sangatlah berbeda.Seperti perusahaan yang memerintahkan pegawainya untuk membuat rekening atas nama pegawai tersebut namun yang mengkelola rekening tersebut adalah pimpinan perusahaan dengan alih-alih perpindahan dana perusahaan, padahal sebenarnya hal tersebut bisa dimanfaatkan dari pihak perusahaan untuk mnyembunyikan dana perusahaan agar terhindar dari pajak.Padahal sebenarnya perusahaan sendiri diwajibkan menjamin perlindungan/jaminan terhadap hak-hak pekerja/buruh.Perlindungan ini dimulai dengan adanya kewajiban bahwa perusahaan harus yang berbadan hukum.Apabila dikaitkan dengan masalah perlindungan kerja dan syarat-syarat kerja, maka hal ini adalah masalah yang sangatlah kompleks karena akan berkaitan juga dengan kesehatan kerja,keselamatan kerja,upah,kesejahteraan dan jamsostek.Undang-Undang No. 13 tahun 2003 telah mengatur semuanya didalam pasal-pasal yang terkaji didalam pasal tersebut.menurut Soepomo, perlindungan tenaga kerja menjadi tiga macam yaitu:

1. Perlindungan ekonomis, yaitu perlindungan tenaga kerja dalam bentuk penghasilan yang sangat cukup, dan termasuk bila tenaga kerja tidak mampu bekerja diluar kehendaknya

2. Perlindungan sosial, perlindungan tenaga kerja dalam bentuk jaminan kesehatan kerja dan kebebasan berserikat serta perlindungan hak untuk berorganisasi

3. Perlindungan teknis, perlindungan tenaga kerja dalam bentuk keamanan serta keselamatan kerja. ${ }^{28}$

Setiap karyawan berhak mendapat perlindungan dan bantuan dari pemerintahan melalui dinas tenaga kerja bilamana mengalami PHK secara tidak adil. Dalam penjelasan tersebut perusahaan memiliki hak yang tercantum dalam uraian Undang-Undang Ketenagakerjaan, yakni dalam UU Nomor 13 Tahun 2003 Tentang Ketenagakerjaan. Hak-hak itu ada beberapa yang salah satunya adalah perusahaan berhak melakukan pemutusan hubungan kerja terhadap pekerja/buruh jika melanggar ketentuan yang telah disepakati sebelumnya.Maka dari itu apabila memang didalam perjanjian kontrak kerja tidak ada perjanjian bahwa rekening pegawai akan dipergunakan maka pegawai tidak dapat dikeluarkan dengan alasan tidak berkenan rekeningnya dipakai oleh perusahaan karena itu adalah salah satu bentuk perlindungan hak dan kewajiban dari pegawai itu sendiri.

Perkembangan globalisasi ekonomi saat ini sangat berpotensi akan terjadinya criminal/kejahatan dalam bidang korporasi yang dapat menimbulkan kerugian bagi korbannya yang didukung dengan adanya kemunculan dan berkembangnya ilmu pengetahuan dan juga teknologi informasi. Korporasi sendiri adalah suatu gabungan orang yang dalam pergaulan hukum bertindak bersama-sama sebagi suatu subjek hukum tersendiri suatu personafikasi.

${ }^{28}$ Imam Soepono, Hukum Perburuhan Dalam Bidang Hubungan Kerja (Jakarta: Djambatan, 1987).h. 51 
Korporasi adalah badan hukum yang beranggotakan tetapi mempunyai hak serta kewajiban sendiri terpisah dari hak dan kewajiban anggota masing-masing. Apabila membahas mengenai perlindungan konsumen serta hak-hak nasabah terutama karyawan di suatu perusahaan yang rekeningnya tengah dipakai perusahaan untuk transaksi pemindahan dana perusahaan, banyak sekali aspek yang didapat. Bagi karyawan yang tidak menjalankan tugas atau juga kewajibannya kedalam bekerja maka dia tidak akan mendapatkan upah.

Didalam Undang-Undang tersebut tidak dijelaskan apabila rekening pegawai atau karyawan dapat dipergunakan oleh perusahaan yang berbentuk Perseroan Terbatas. Dalam hal ini banyak sekali faktor-faktor pidana yang dapat dimanfaatkan oleh perusahaan apabila karyawan mau atau tidak segan-segan untuk memberikan pin ATM atau data pribadi rekeningnya terhadap perusahaan untuk proses transaksi antar perusahaan.Maka dari itu karyawan harus lebih berhati-hati lagi dan mempertegas untuk menolak apabila rekeningnya memang sengaja akan dipakai oleh perusahaan, terlebih lagi apabila memang tidak ada kontrak tertulis sebelumnya mengenai pemakaian rekening karyawan tersebut.Karna di era globalisasi ini semakin beragam tindak kejahatan yang bisa dilakukan dan bisa menimpa orang lain yang tidak bersalah.Yang paling banyak terjadi adalah apabila Perusahaan seperti Perseroan Terbatas (PT) yang hendak menyembunyikan asset dan juga menghindari pajak. Strategi ini seringkali digunakan beberapa perusahaan untuk menghindari laporan pajak dengan memecah saldo perusahaan ke beberapa rekening karyawan bahkan rekening pribadi pemegang saham.Hal lainnya yang bisa terjadi adalah dengan menyembunyikan asset pribadi dari hasil korupsi yang tentunya tidak diketahui oleh karyawan.Salah satu efek negative bagi perusahaan adalah korupsi bisa menjadi hal biasa sehingga menjadi terbiasa bagi perusahaan memiliki sifat tidak jujur dan tidak bertanggungjawab. ${ }^{29}$

\section{Upaya Hukum Bagi Karyawan yang Rekeningnya Disalahgunakan Oleh Perusahaan}

Perkembangan globalisasi ekonomi saat ini sangat berpotensi akan terjadinya kriminal/kejahatan dalam bidang korporasi yang bisa memunculkan kerugian untuk korbannya yang didukung dengan meningkatnya ilmu wawasan dan juga sitem teknologi informasi. Korporasi ialah sebuah korelasi orang yang di lingkup hukum berlaku menjadi suatu objek hukum mandiri yang personafikasi. Perusahaan sendiri adalah badan hukum yang mandiri tetapi mempunyai hak serta tugasnya sendiri namun berbeda dengan hak juga kewajiban satuan masing-masing. ${ }^{30}$ Kejahatan yang dilaksanakan dari karyawan kepada bagian lain contohnya seperti mendapatkan grativikasi dari agen maupun dari pencari kerja, tidak menjadi pada kejahatan perusahaan dengan anggapan jika perusahaan sudah memberi perlakuan hukum kepada para tersangka dengan metode melaporkan terhadap penegak hukum.Jika terdapat bukti jika suatu perusahaan sudah melaksanakan tindakan pidana korporasi, dalam UndangUndang PT Indoensia, semua member direksi dan dewan komisaris bertanggung jawab dengan tercakup semua (terseret semua). Hingga mereka yang ingin jadi direktur SDM mesti harus ingat akan kejadian itu. Korporasi sendiri juga memiliki sebagai berikut ini, yaitu mempunyai aset tersendiri yang terbagi dari aset individu-individu yang sudah menunaikan aktivitas di Lembaga-lembaga hukum itu, mempunyai keberhakan-keberhakan juga keharusan yang mestinya terbagi dari keberhakan-keberhakan dan juga keharusan dari individu-individu yang melaksanakan mempunyai badan hukum itu, mempunyai tujuan tertentu dan posisinya juga tidak berkaitan kepada individu-individu secara personal sebab hak serta keharusannya terus

\footnotetext{
${ }^{29}$ Syed Hussein Alatas, The Sociology of Corruption, ed. 2. (Singapore: Delta Orient Pte. Ltd, 1999). h.62

${ }^{30}$ Chaidir Ali, Badan Hukum (Bandung, 1987). h.64
} 
aka nada walaupun individu-individu yang menjalamkannya akan bertukar. ${ }^{31}$ Kejahatan korporasi disini merupakan suatu wujud kejahatan ddi bidang bisnis yang muncul sebab peningkatan teknologi yang makin update juga tingkat intelegensia dari individu.Disebabkan dari neo liberalisme pada sisi ekonomi hingga tujuan awalnya ialah menghimpun modal yang sebanyak-banyaknya lewat profit dari perusahaan sehingga hal ini dapat mudah memunculkan kejahatan dalam bidang perusahaan. ${ }^{32}$ Kejahatan korporasi ialah wujud dari kejahatan dengan tingkat internasional yang menyebabkan harus adanya kerjasama antar Negara guna membentuk aturan dengan tujuan menghindari juga jika meninjau akibatnya amat serius untuk keberlangsungan individu. Berikut adalah berbagai jenis kejahatan perihal ruang lingkup melalui kejahatan korporasi:

a) Crime For Corporation

Kejahatan korporasi ini ialah satu diantara wujud white collar crimes. Dengan makna yang banyak, kejahatan perusahaan ini acap kali ada. Wujud-wujud dan korban kejahatan perusahaan secara umum yakni persekusi kepada hak-hak pembeli, kejahatan lingkungan hidup, kejahatan dinagian pajakn dengan tingkat maupun ruang lingkup korban yang amat besar yakni pembeli, masyarakat dan juga Negara.

\section{b) Crime Against Corporation}

Kejahatan yang dilaksanakan dari individu maupun seorang personal yang berkorelasi langsung terhadap sebuah jabatan yang cukup pada ruang lingkup itu. Kejahatan ini tidak hanya dilaksanakan dari individu yang mempunyai pangkat maupun dari juga oleh siapapun yang terkait dengan ruang lingkup pangkat itu. Hal tersebut dilaksanakan sebagai keuntungan pribadi maupun individu bukan sebagai keuntungan lembaga hukum. Sebab itu kejahatan ini memiliki kesuaian dengan perilaku pidana korupsi. Kejahatan dari pangkat ini diantaranya idalah dokter ahli farmasi, karyawan yang menkorupsi aset korporasi maupun dinas pemerintahan yang mana mereka bekerja.

\section{c) Criminal Organization}

Arti korporasi dalam area kejahatan yang dimanajemen ini ialah sejumlah individu yang dengan sengaja dimunculkan guna melaksanakan kejahatan. Organisasi ini menjadi suatu gabungan yang jauh besar di lingkup penjahat. Dengan artian itu tanda dari kelompok ini ialah bersifat illegal dari suatu kelompok itu. Dengan kelompok criminal itu maka akan terwujud suatu kode rahasia yang nantinya dipunyai oleh para membernya dan hal ini diwujudkan menjadi salah satu karakter kelompok maupun gerombolan.Nilai sikap criminal tersebut yang nantinya mewujudkan budaya criminal yang bersifat prevelage dan dimunculkan oleh membernya sendiri sesuai perjanjian. ${ }^{33}$

Ada berbagai macam jenis-jenis kejahatan dalam korporasi yang salah satunya yang paling sering terjadi adalah korupsi.Korporasi dapat dinyatakan untuk melaksanakan perkara pidana korupsi sesuai yang sudah dicantumkan didalam [asal 2 ayat (1) UU PTPK jika orangorang dalam perusahaan baik pengurus ataupun pekerja perusahaan itu, maupun individuindividu internal yang sesuai kuasa dari perusahaan itu baik individu maupun kolektif bersama saat melakukan aktivitas perusahaannya sudah dengan berkonfrontasi hukum

\footnotetext{
${ }^{31}$ Mochtar Kusumaatmadja and B. Arief Sidharta, Pengantar Ilmu Hukum, Suatu Pengenalan Pertama Berlakunya Ruang Lingkup Berlakunya Ilmu Hukum, Buku I. (Bandung, 2000). h. 80-81

${ }^{32}$ Yusuf Shofte, Pelaku Usaha, Konsumen Dan Tindak Pidana Korporasi (Jakarta: Gjalia Indonesia, 2002). h. 45

${ }^{33}$ Muladi, Pertanggungjawaban Pidana Korporasi Dalam Kerangka Lingkungan Hukum Bisnis (Surabaya, 2010). h. 3
} 
menginvestasikan perusahaan itu sendiri maupun individu seorang maaupun perusahaan lain saat perlakuan itu bisa mrugikan finansial maupun perekonomian Negara. Pada hal korupsi ini dilaksanakan oleh juga atas nama perusahaan yang mestinya bisa dijatuhkan sebagai tersangka maupun bisa dituntut atau dihukumi pidana hanya ada dua opsional yakni perusahaannya maupun jajaran perwakilan pimpinan perusahaan yang dijatuhi atas perkara pidana korupsi yang sudah dilaksanakan oleh ataupun dengan nama perusahaan pidana pokok yang bisa diberikan hanyalah pidana denda, Sesuai perihal itu maka individu maupun perusahaan bisa diberikan pidana penjara maupun denda ialah tidak sesuai.

Kejahatan korporasi ini ialah seluruh tindakan pidana yang dilaksanakan oleh orang maupun perorangan yang bisa ditujukan bagi suatu perusahaan sebab aktivitas-aktivitas yang dilaksanakan dari pekerja maupun karyawannya,Korban dari kejahatan korporasi ini bermacam-macam yakin korban tidak sadar dirinya menjadi korban yang dalam faktanya seperti pegawai yang rekeningnya dipakai oleh perusahaan untuk penghindaran pajak perusahaan atau disalahgunakan hal lainnya dan pegawai tidak tau apa-apa mengenai hal tersebt namun akan terkena dampaknya, korban dari kejahatan perusahaan bersifat abstrak,penyebaran korban yang sangat meluas, dan korban yang ikutserta maupun terdapat hubungannya dengan kejahatan korporasi.Banyak sekali terjadi tindak pidana korporasi yang merugikan karyawannya dan bisa berdampak buruk ke divisi lainnya juga.Perusahaan akan memiliki berbagai cara agar bisa memanipulasi keuangan perusahaan dengan kata lain menyembunyikan dana perusahaan untuk menghindari pajak dengan cara menitipkan dana tersebut ke rekening karyawannya. Tidak hanya karyawan saja, bahkan mantan direksi atau divisi lainnya pun juga bisa terkena imbasmya, yang paling parah apabila karyawan tidak mau atau enggan untuk memberikan rekeningnya atau menolak untuk membuat rekening baru untuk dikelola oleh perusahaan, karyawan biasanya diancam untuk dilakukan Pemutusan Hubungan Kerja oleh perusahaan ditempat karyawan tersebut bekerja.Karyawan pun biasanya akan memberikan rekening serta mengikuti permintaan perusahaan untuk membuat rekening baru dengan terpaksa karena mereka enggan untuk dikeluarkan apalagi di masa pandemi seperti ini untuk mencari pekerjaan sangat susah dan bisa mempersulit keadaan karyawan.Hal ini perlu dilakukan adanya upaya perlindungan hukum yang dimiliki oleh karyawan untuk mempertahankan kedudukannya di suatu perusahaan tanpa adanya rasa terancam untuk dikeluarkan dari pekerjaannya.Apabila perusahaan melakukan pemaksaan atas pengunduran diri yang harus dilakukan karyawannya karena tidak mau memberikan rekening dan enggan memberikan bantuan berupa pembukaan rekening baru untuk keperluan perusahaan, dan tidak didasarkan atas kemauan sendiri maka karyawan sendiri harus dapat membuktikan bahwa surat pengunduran diri yang dibuat itu atas dasar paksaan dan bukan kemauannya sendiri. Hal serupa pernah dijelaskan juga bahwa dengan adanya surat pengunduran diri, maka surat tersebut dianggap sah apabila tidak dapat dibuktikan sebaliknya. Artinya karyawan harus dapat membuktikan adanya paksaan dalam penandatangan surat pengunduran diri tersebut. Sehingga apabila terbukti adanya paksaan, maka surat tersebut dapat dimintakan pembatalannya dan karyawan dapat mengklain PHK sepihak tersebut ke Pengadilan Hubungan Industrial (PHI).Untuk memperjuangkan hak kayawan termasuk gaji yang belum dibayarkan karena ancaman tersebut, karyawan dapat menggugat perusahaan ke PHI dan tentunya dengab terlebih dahulu mengupayakan perundingan bipartit secara musyawarah untuk mencapai mufakat.Menurut Undang-Undang Nomor 2 Tahun 2004 Tentang Penyelesaian Perselisihan Hubungan Industrial, perselisihan yang timbul karena tidak adanya kesesuaian pendapat 
mengenai pengakhiran hubungan kerja yang dilakukan oleh salah satu pihak.Menurut Juanda Pangaribuan, sengketa mengenai perselisihan pemutusan hubungan kerja, fakta yang harus dikemukakan oleh penggugat adalah ${ }^{34}$ :
a. Kapan hubungan kerja dimulai
b. Kapan hubungan kerja berakhir
c. Siapa yang mengakhiri hubungan kerja
d. Apa alasan pengakhiran hubungan kerja
e. Bagaimana cara perusahaan melakukan pemutusan hubungan kerja
f. Berapa gaji per bulan
g. Tunjangan apa saja yang diterima
h. Status hubungan kerja (kontrak atau permanen)

Karyawan bisa menyerahkan ke pengadilan untuk di eksekusi sesuai peraturan yang telah ditetapkan oleh hukum acara perdata yang biasanya untuk melakukan eksekusi pengadilan akan mengeluarkan penetapan yang dikeluarkan oleh hakim yang berisi teguran atau peringatan untuk melaksanakan putusan.Dalam perkara perdata, penetapan yang dikeluarkan oleh hakim berisi teguran atau peringatan untuk melaksanakan putusan sesungguhnya ada dua upaya hukum atas putusan pengadilan hubungan industrial, yakni upaya hukum biasa atau kasasi dan upaya hukum luar biasa atau Peninjauan Kembali (PK). Adapun jangka waktu pengajuan kasasi adalah empat belas hari sejak putusan tersebut dibacakan dalam persidangan atau terhitung sejak tanggal menerima pemberitahuan putusan. Jika terdapat bukti baru yang bersifat menentukan pada saat waktu perkara diperiksa tidak dapat ditemukan, maka upaya hukum yang dapat dilakukan adalah Peninjauan Kembali (PK) yang jangka waktu pengajuannya adalah seratus delapan puluh hari sejak ditemukannya surat-surat bukti yany hari serta tanggalnya ditemukan harus dinyatakan dibawah sumpah dan disahkan oleh pejabat yang berwenang. Jadi ada upaya hukum ataupun bentuk perlindungan dan perlawanan yang bisa dilakukan karyawan yaitu dengan cara tersebut ataupun perusahaan harus memberlakukan perjanjian kontrak secara sesuai dan detail agar sesuai dengan apa yang akan dikerjakan dan dilakukan karyawan bisa sesuai perjanjian kontrak kerja dan tidak merasa terancam bahwa karyawan tersebut akan di PHK secara sepihak.

\section{KESIMPULAN}

Dalam era globalisasi seperti saat ini, banyak sekali berbagai macam jenis tindak pidana yang terjadi dalam berbagai aspek, dan terutama dalam bidang perbankan dan berkaitan dengan ketenagakerjaan. Sehingga banyak sekali beberapa pihak seperti karyawan atau pegawai perusahaan yang akan terkena dampaknya apabila tidak berhati-hati. Salah satu contoh dalam tindak pidana korporasi seperti ini adalah korupsi, pencucian uang dan yang sering terjadi adalah ketika beberapa perusahaan menyembunyikan dana perusahaannya ke beberapa rekening pegawai nya untuk mengalihkan dana dan menghindari pajak. Maka dari itu pegawai harus lebih berhati-hati lagi dan mempertegas untuk menolak apabila rekeningnya memang sengaja akan dipakai perusahaan untuk perpindahan dana perusahaan tanpa adanya perjanjian kontrak dan aturan yang jelas sebelumnya. Strategi seperti ini sering digunakan beberapa perusahaan untuk menghindari pajak dengan memecah saldo perusahaan ke beberapa rekening karyawan bahkan rekening pribadi pemegang saham. Pegawai bisa saja terdampak atau

${ }^{34}$ Juanda Pangaribuan,2017,Seluk Beluk Hukum Acara Pengadilan Hubungan Industrial.Jakarta: MISI. 
dianggap melakukan perbuatan perbantuan korupsi kepada perusahaan apabila rekeningnya disalahgunakan untuk korupsi atau pencucian uang. Didalam Kitab Undang-Undang Hukum Perdata pasal 1320 yang menjelaskan bahwa syarat sah nya perjanjian adalah disetujui atau adanya kesepakatan antara kedua belah pihak yang melakukan perjanjian, dari hal ini dapat diartikan bahwa apabila perjanjian kontrak kerja awal tidak dinyatakan bahwa rekening pegawai akan digunakan, pegawai berhak menolak untuk rekeningnya digunakan oleh perusahaan guna menghindari hal-hal yang tidak diinginkan. Apabila ditengah kontrak pimpinan perusahaan meminta pegawai untuk membuka rekening baru atas nama pegawai tersebut, namun rekeningnya akan dikelola perusahaan hal tersebut bisa tidak dsepakati oleh pegawai karna apabila tidak adanya kesepakatan diantara kedua belah pihak, perjanjian tersebut dinyatakan tidak sah dan dari segi pajak pun perusahaan juga salah karna sudah mencoba melakukan kecurangan pengalihan pajak.Saat ini juga sudah diterbitkan Peraturan Pemerintah Pengganti Undang-Undang Nomor 1 Tahun 2017 tentang akses informasi keuangan untuk kepentingan perpajakan yang dimana pajak bisa menelusuri ke pihak bank untuk perusahaan yang memang sengaja memecah dana perusahaan ke rekening pegawainya.Pegawai sendiri harus mempunya perlindungan yang bertujuan untuk menjamin berlangsungnya sistem hubungan kerja yang harmonis tanpa adanya tekanan dari pihak yang kuat terhadap pihak yang lemah.Dalam mewujudkan kesejahteraan burug atau pekerja sebuah perusahaan harus dibuatkan peraturan tertulis yang mana peraturan tersebut berisi tentang apa yang boleh dilakukan dan tidak boleh dilakukan oleh perusahaan, karena perusahaan sendiri merupakan sebuah badan usaha yang memang dibuat untuk mencari keuntungan atau laba yang setiap perusahaan nya pun harus memiliki dasar dan juga kekuatan hukum.

\section{DAFTAR PUSTAKA}

Alatas, Syed Hussein. The Sociology of Corruption. Ed. 2. Singapore: Delta Orient Pte. Ltd, 1999.

Ali, Chaidir. Badan Hukum. Bandung, 1987.

Ahmad Jailani, 2019, Perlindungan Hukum Bagi Nasabah Terkait Dengan Rahasia Bank,Jurnal Ilmi Hukum, Universitas Malang

Asikin, 1997, Zaenal. Pokok-Pokok Hukum Perbankan Di Indonesia. II. Jakarta: Raja Grafindo Persada

C.S.T. Kansil, Christine. Pokok-Pokok Pengetahuan Hukum Dagang Indonesia. Jakarta, 2013. Dirjosisworo, Soedjono. Hukum Perusahaan Mengenai Bentuk-Bentuk Perusahaan (Badan Usaha) Di Indonesia. Bandung: Mandar Maju, 1997.

Djumhana, Muhammad. Rahasia Bank (Ketentuan Dan Penerapannya) Di Indonesia. Bandung: PT. Citra Aditya Bakti, 1996.

Dwi Yuli Meisinta, 2018,Perlindungan Hukum Terhadap Nasabah Atas Tindakan Fraud yang Dilakukan Oleh Pegawai Bank,Fakultas Hukum, Universitas Jember

Harahap, M. Yahya. Hukum Perseroan Terbatas. Sinar Grafika, 2009.

Hartono, Sri Redjeki. Bentuk-Bentuk Kerjasama Dalam Dunia Niaga. Semarang, 1985. Hendrik Agus Setiawan, 2018.Perlindungan Nasabah Terkait Praktik Pembukaan Rahasia Bank Oleh Pegawai Bank Dalam Proses Penegakan Hukum Tindak Pidana Pencucian

Uang dihubungkan Dengan Asas Kepastian Hukum, Jurnal hukum dan pembangun

Imannsyah,Addy,2011.Perlindungan Negara terhadap Kebebasan Beragama DiIndonesia

(Studi Kasus Surat Keputusan Gubernur Jawa Timur No.188/94/KPTS/013/2011

Tentang Larangan Aktivitas Jemaat Ahmadiyah Indonesia (JAI)di Jawa Timur), Tesis,

Fakultas Hukum Universitas Airlangga, Surabaya. 
Kanyaka Prajnamita, 2019, Perlindungan Hukum Terhadap Tenaga Kerja Perempuan Berdasarkan Undang-Undang Nomor 13 tahun 2003 tentang Ketenagakerjaan,Jurnal Fakultas Hukum,Universitas Diponegoro

Kasmir. Dasar-Dasar Perbankan. Jakarta: PT. Raja Grafindo Persada, 2008.

Khakim, Abdul. Dasar-Dasar Hukum Ketenagakerjaan Indonesia. Bandung: PT. Citra Aditya Bakti, 2014.

Khanif, Al,2010. Hukum \& Kebebasan Beragama di Indonesia, LaksBang Mediatama, Yogyakarta.

Komnas HAM, 2018.”Upaya Negara Menjamin Hak-Hak Kelompok Minoritas di Indonesia”,Sebuah Laporan Awal, Jakarta.

Mahendra M. Sinaga, Vol 2 No. 2(2020), Perlindungan Hukum Terhadap Pelanggaran Kerahasiaan Data Pribadi Nasabah Yang Dilakukan Oleh Pegawai Bank Pada Bank Mandiri (Persero) TBK., Jurnal Teknologi, Fakultas Hukum UPMI

Mulia,SitiMusdah, makalahyangdisampaikanpadaacaraKonsultasiPublikuntukAdvokasiterhad apRUUKUHPdiselenggarakanolehAliansiNasionalReformasiKUHP,tanggal 4Juli 2007 di Jakarta.

Manulang, Sedjun H. Pokok-Pokok Ketenagakerjaan. Jakarta: Rineka Cipta, 1987.

Muladi. Pertanggungjawaban Pidana Korporasi Dalam Kerangka Lingkungan Hukum Bisnis. Surabaya, 2010.

M. Sri Soemantri,1987. Prosedur dan Sistem Perubahan Konstitusi,Alumni Bandung.

Nowak, Manfred,2003.Pengantar pada Rezim HAM Internasional, terjemahan oleh Sri Sulastini, Jakarta: Departemen Hukum dan HAM Indonesia.

Rhona,K.M.Smith,dkk,2008.HukumHakAsasi Manusia,PUSHAM UII,Yogyakarta.

Rithi, Hyronimus,2011.Filsafat Hukum, Universitas Atma Jaya, Yogyakarta.

Sihombing,UliParulian,2008.MenggugatBakorPakem:KajianHukumTerhadap PengawasanAgamadanKepercayaandiIndonesia,ILRC,Jakarta.

Syafi'ie,M.,2012.ToFulfillandToProtect:MembacaKasus-KasusAktualtentangHakAsasi Manusia, PUSHAM UII, Yogyakarta.

Tenrisangka, Alifah Pratisara,2017.Perlindungan Penganut Kepercayaan Di Indonesia, Universitas Airlangga, Surabaya.

Twiss, Summer B.danJohn Kelsay,2007.Agama dan Hak-Hak Asasi Manusia, Institut DIAN, Yogyakarta.

Utomo,Fajar Satrio, 2017,Perlindungan Hukum Bagi Jemaat Ahmadiyah, Univesritas Airlangga, Surabaya.Update Indonesia - Volume XI, No. 9 